\title{
Cutaneous squamous cell carcinoma complicating hidradenitis suppurativa: a review of the prevalence, pathogenesis, and treatment of this dreaded complication
}

\author{
Stephanie Chapman ${ }^{1}$, Daniel Delgadillo III ${ }^{1}$, Cara Barber ${ }^{1}$, Amor Khachemoune ${ }^{2,3} \bowtie$
}

\begin{abstract}
Hidradenitis suppurativa (HS) is a chronic and debilitating skin disorder characterized by the formation of painful abscesses, draining sinus tracts, and scarring, predominantly in skin folds such as the axillae and the perineum. The exact prevalence of HS is unknown because the disease is often underreported, but it has been estimated to be as high as $4.1 \%$. HS is three times more prevalent in women than in men. Various comorbidities have been associated with HS, including inflammatory bowel disease and squamous cell carcinoma (SCC). The transformation of chronic HS to SCC is often considered the most severe complication of HS. The prevalence of SCC associated with HS is approximately $4.6 \%$, and is more common among men. It is likely that the chronic irritation and inflammation characteristic of HS drive the malignant transformation to SCC, and recent work has identified other potential risk factors for this malignant transformation, including human papillomavirus (HPV) infection and tobacco use. Treatment modalities have expanded in recent years to include triple antibiotic therapy, immunomodulatory biologic agents, laser therapy, and surgical excision. Knowledge of these comorbid associations of HS, especially the malignant transformation to SCC, is highly important for the management and follow-up of this chronic disease.
\end{abstract}

Keywords: squamous cell carcinoma, hidradenitis suppurativa, skin cancer

Received: 12 October 2017 | Returned for modification: 5 December 2017 | Accepted: 17 December 2017

\section{Introduction}

Hidradenitis suppurativa (HS) was first described in the medical literature in 1839 by Alfred Velpeau (1). In 1854, the French surgeon Aristide Verneuil further described the disease and its association with sweat glands $(2,3)$. Since that time HS has been synonymous with Verneuil's disease, and is often referred to as la maladie de Verneuil.

HS is characterized by deep-seated, inflammatory nodules that arise in areas of the body rich in apocrine glands, including the axillae and the groin. HS can be described clinically using the Hurley staging system (Table 1). The disease typically presents after puberty, with a peak incidence in the second and third decades of life. Prevalence is greater among women (75\%) than among men (25\%) (4). Recent work suggests the disease may be triggered in individuals with a genetic predisposition (5). HS begins with occlusion of a hair follicle, leading to hyperkeratosis, hyperplasia, dilation, and the subsequent rupture of the follicle, releasing keratin and bacteria into the dermis. An inflammatory immune response is then triggered and secondary bacterial infection ensues (4). Although rare, the development of squamous cell carcinoma (SCC) superimposed on chronic HS has a high morbidity. Studies have shown that long-lasting HS and the involvement of the buttocks and perineal areas increase the risk of malignant transformation to SCC $(6,7)$. When SCC does arise in HS it is usually well differentiated; however, despite the theoretical good prognosis, the combination of SCC and HS is often associated with early metastasis and high mortality rates (8). The development of SCC is likely multifactorial, and may be explained by the chronic irritation and inflammation characteristic of HS in association with other risk factors such as tobacco use $(6,9)$.
A search of the PubMed, Embase, and MEDLINE databases was conducted to identify articles describing cases of SCC in patients with HS. All of the articles reviewed were published in English. Search terminology included: "Hidradenitis Suppurativa" and "Hidradenitis Suppurativa AND Squamous Cell Carcinoma."

Table 1 | Hurley classification system.

\begin{tabular}{ll}
\hline Stage & Clinical description \\
\hline Stage I & $\begin{array}{l}\text { Single or multiple recurrent abscesses without sinus tract } \\
\text { formation and scarring }\end{array}$ \\
Stage II & $\begin{array}{l}\text { Abscesses with one or more sinus tracts separated by normal } \\
\text { skin } \\
\text { Stage III }\end{array}$ \\
$\begin{array}{l}\text { Multiple, interconnected sinus tracts that are not separated } \\
\text { by normal skin }\end{array}$ \\
\hline
\end{tabular}

\section{Prevalence of squamous cell carcinoma in patients with chronic hidradenitis suppurativa}

A review of the articles found 85 cases of SCC arising from HS reported in the English literature to date (6-13). A 2016 report by Jourabchi et al. (6) described 80 of these cases, and we found five additional cases published since that time (Table 2). Among these five new cases, the mean history of HS prior to SCC diagnosis was 26 years. The mean age at diagnosis was 52 years. SCC developed from longstanding HS of predominately the gluteal and perianal areas. A biopsy of malignant tissue was tested for human papillomavirus (HPV) in two of the five cases, and was negative in both cases. A history of tobacco use was reported in two cases $(9,10)$.

The diagnosis of SCC in chronic HS is particularly challenging because painful and inflammatory HS lesions may be difficult to distinguish from malignant transformation (6). Thus, a low threshold for biopsy is often recommended by clinicians to diagnose 
SCC as early as possible.

\section{Pathophysiology of hidradenitis suppurativa and the malignant transformation to squamous cell carcinoma}

\section{Genetics}

HS can occur sporadically or be familial. It is estimated that a little over one-third of patients with HS have a positive family history (14). Although several genetic loci have been implicated in the disease process, a single causative gene is yet to be identified (4). Loss of function mutations in the gamma-secretase genes-including presenilin-1, presenilin enhancer-2, and nicastrin-likely play a role $(5,15)$. In mouse models of gamma-secretase deficiency, hair follicles were converted to epidermal cysts, and in nicastrindeficient mice follicular and cystic hyperkeratosis developed (14).

Gamma-secretase is a multisubunit protease complex that targets amyloid precursor protein (APP) and Notch. Gammasecretase mutations implicated in HS were first identified in the Han Chinese population. Since then these mutations have been reported in patients with HS in the United Kingdom, France, Japan, and the United States (14).

Inherited or acquired defects in the Notch signaling pathway may also play a role, because Notch is an important protein for normal follicle development and regulation of the immune response (15). Keratinocytes in the epidermis and adnexal structures express Notch ligands and receptors. Notch overactivity in hair follicles leads to abnormal hair formation. Conversely, impaired Notch signaling leads to the conversion of hair follicles into epidermal cysts and disrupts hair follicle homeostasis, leading to a rupture of the follicles and the initiation of an inflammatory immune response (16). Additionally, Notch has been shown to act as a tumor suppressor in non-melanoma skin cancers including SCC (16).

\section{Hair follicle occlusion and the inflammatory immune response}

Follicular occlusion of apocrine glands is an early event in HS that contributes to dilation of the hair follicle followed by rupture and discharge of material including keratin, bacteria, corneocytes, and sebum, sparking an inflammatory response (15). Levels of tumor necrosis factor-alpha (TNF-alpha), interleukin-1 beta (IL-1 beta), chemokine ligand 9 (CXCL9), IL-10, IL-11, B lymphocyte chemoattractant, and IL-17A have been shown to be elevated in HS skin $(17,18)$. Immunohistochemical studies of HS surgical specimens from 18 patients demonstrated high levels of antimicrobial peptides (AMPs), including psoriasin and human beta-defensin, in the epidermis. High levels of cathelicidin were also found in epidermal keratinocytes and in eccrine and apocrine sweat gland epithelium (17). AMPs likely play a role in activating the inflammatory immune response by stimulating immune cell chemotaxis and inflammatory cytokine production. High levels of inflammatory cytokines-including alpha melanocyte stimulating hormone, macrophage migration inhibitory factor, TNF-alpha, and IL-8 were also found in the epidermis of HS surgical specimens in these immunohistochemical studies (17).

Chronic states of inflammation produce an environment that favors oncogenesis through the dysregulation of tumor suppressor genes and through self-sufficient growth. HS incites constant infection and inflammation, leading to genetic mutations forming in cell lines that are missed by the tumor suppressor genes and DNA damage checkpoints. Mutations occur more frequently in high stress atmospheres during the increased tissue hyperplasia and hypertrophy that co-occur with the inflammation and damage seen in HS. The immune response to this insult generates free radicals such as reactive oxygen intermediates (ROI), hydroxyl radical $(\mathrm{OH})$, and superoxide $\left(\mathrm{O}_{2}^{-}\right)$. Free radicals lead to oxidative damage and the nitration of DNA bases, which increase the risk for DNA mutations and the potential malignant transformation of long-standing HS to SCC (19).

Kurokawa et al. studied the cytokeratin (CK) expression in two cases of SCC arising from HS: one well differentiated and one poorly differentiated (20). In the well-differentiated case of SCC, CK1 and CK10 expressions were downregulated, whereas CK14 expression was upregulated. In the poorly-differentiated case of SCC, CK1 and CK10 were not expressed, but simple epithelial keratins (CK8, 18, and 19) were expressed. These changes in CK expression, especially the downregulation of CK1 and CK10, provide the first indication of malignant transformation to SCC-associated HS (20).

Table 2 | New cases of squamous cell carcinoma arising from hidradenitis suppurativa reported in the literature since Jourabchi et al. (6).

\begin{tabular}{|c|c|c|c|c|c|c|c|c|c|}
\hline $\begin{array}{l}\text { Author } \\
\text { (reference) }\end{array}$ & Year & Age (years) & $\operatorname{Sex}(M / F)$ & $\begin{array}{l}\text { Duration of } \\
\text { chronic HS } \\
\text { prior to SCC } \\
\text { (years) }\end{array}$ & $\begin{array}{l}\text { Location of } \\
\text { SCC }\end{array}$ & $\begin{array}{c}\text { Metastasis } \\
(\mathrm{Y} / \mathrm{N})\end{array}$ & HPV status & $\begin{array}{c}\text { Tobacco use } \\
(\mathrm{Y} / \mathrm{N})\end{array}$ & Outcome \\
\hline Huang (9) & 2017 & 60 & $M$ & 15 & Buttock & $\mathrm{N}$ & Negative & $Y$ & $\begin{array}{c}\text { Radical resection with } \\
3 \mathrm{~cm} \text { free margin. Split } \\
\text { thickness skin graft. }\end{array}$ \\
\hline Joglekar (10) & 2016 & 46 & M & 33 & $\begin{array}{l}\text { Gluteal/ } \\
\text { perianal }\end{array}$ & $Y$ & Unknown & $\mathrm{Y}$ & $\begin{array}{l}\text { Death secondary to } \\
\text { metastatic spread } \\
\text { of SCC to the pleura } \\
\text { and subsequent } \\
\text { respiratory failure. }\end{array}$ \\
\hline Hessam (11) & 2016 & 63 & $\mathrm{~F}$ & 25 & $\begin{array}{l}\text { Gluteal/ } \\
\text { perianal }\end{array}$ & $\mathrm{Y}$ & Negative & Unknown & $\begin{array}{l}\text { Death shortly after } \\
\text { surgical resection of } \\
\text { tumor. }\end{array}$ \\
\hline \multirow[t]{2}{*}{ Yon (13) } & 2017 & 42 & $\mathrm{~F}$ & 24 & Perineal & $\mathrm{Y}$ & Unknown & Unknown & \multirow{2}{*}{$\begin{array}{l}\text { Alive and undergoing } \\
\text { chemotherapy and } \\
\text { radiation after wide } \\
\text { local excision at time } \\
\text { of publication. }\end{array}$} \\
\hline & & 54 & $F$ & 36 & Perineal & $Y$ & Unknown & Unknown & \\
\hline
\end{tabular}

$\mathrm{M}=$ male, $\mathrm{F}=$ female, $\mathrm{HS}=$ hidradenitis suppurativa, $\mathrm{SCC}=$ squamous cell carcinoma, $\mathrm{Y}=\mathrm{yes}, \mathrm{N}=$ no. 


\section{Bacterial infection}

Both aerobic and anaerobic bacteria have been isolated from HS lesions. A recent study determined the prevalence of bacterial isolates from 90 different HS lesions in 50 consecutive patients (21). Anaerobic non-Enterobacteriaceae (42\%), coagulase-negative staphylococci (26\%), and coagulase-positive staphylococci (26\%) were the most prevalent isolates (21). A retrospective study investigating gram-positive microbial colonization of HS lesions in 27 patients found that $71 \%$ of patients were colonized by gram-positive bacteria in the form of biofilms and microcolonies (22). Another study examining HS lesions at the time of surgery revealed biofilm formation of sinus tracts, further suggesting biofilms may play a role in the pathogenesis of HS (23).

\section{Environmental factors}

Obesity and smoking are two environmental factors that contribute to the incidence and severity of $\mathrm{HS}(4,15)$. Moreover, tobacco use and HPV infection may be associated with the malignant transformation of chronic HS into cutaneous SCC (6). Obesity increases mechanical stress and friction, thereby increasing the occlusion and rupture of hair follicles and the worsening of HS. Tobacco smoke contains various chemicals that interact with the nicotinic acetylcholine receptors and aryl hydrocarbon receptors on keratinocytes, thereby inducing acanthosis, epithelial hyperplasia, and cornification. Fibroblasts and immune cells are also activated to release proinflammatory cytokines such as TNF-alpha, IL-1 alpha, IL-1 beta, and IL-8 (15). Additionally, recent work by Jourabchi et al. found that $80 \%$ of individuals that developed SCC from chronic HS used tobacco (6). Another retrospective study by Lavogiez et al. also noted the connection between smoking and the development of SCC (8). In that study, a significant number of heavy smokers (> 30 pack-year history) developed SCC (10 out of 13 cases). It is postulated that high nicotine levels may contribute to the malignant transformation by promoting follicular plugging, possibly through increased chemotaxis of neutrophils, which leads to a greater inflammatory response and the development of SCC (24).

Jourabchi et al. also found that, among patients with longstanding HS that developed SCC, $72.7 \%$ were positive for alpha$\mathrm{HPV}$, and $87.5 \%$ were positive for beta-HPV. Associations between HPV and cutaneous SCC have been reported in the literature (25, 26). A 2016 meta-analysis demonstrated a significant association between beta-HPV and an increased risk for the development of cutaneous SCC (25). Studies conducted by Lavogiez et al. also found a connection between HPV-16 infection in the anogenital region and SCC (8). The risk of acquiring HPV is heightened by some of the biological pharmaceuticals used in HS treatment, such as anti-TNF-alpha agent infliximab. The use of biological agents such as infliximab, etanercept, and adalimumab, is a newer treatment option usually reserved for more severe cases of HS (8). These treatments work by attenuating the host immune response to reduce inflammation; however, they also leave the patient at risk for reactivating latent infections.

\section{Management of hidradenitis suppurativa and squamous cell carcinoma}

Medical management of HS often involves using a combination of therapies to control the disease (Table 3). Antibiotics are often the first-line treatment for HS, but recent work has raised concerns regarding antibiotic stewardship for the treatment of this condition. A cross-sectional study conducted on 239 patients with HS treated with antibiotic therapy demonstrated increased rates of antimicrobial resistance among this population as compared to patients with HS not treated with antibiotics (27).

Numerous topical and systemic agents have historically been used to treat HS, and the current understanding of the role of the inflammatory immune response in the pathogenesis of HS has led to the development of new treatment strategies using biologics. TNF-alpha inhibitors, IL-1 inhibitors, and IL-12/23 inhibitors have been shown to be efficacious in treating HS (4). More studies are needed to determine the effect of immunosuppressants on the transformation of HS to SCC because there have been reports in the literature of SCC developing after treatment with infliximab $(28,29)$. Maalouf et al. described a fatal case of SCC complicating HS after five infusions of infliximab (28). Another patient developed sepsis and SCC that resulted in death after treatment with infliximab for severe and longstanding HS (29). The role of immunosuppressants in the transformation of HS to SCC is unclear, because there is significant immune dysregulation at baseline in HS.

In addition to medical management, there are laser and surgical options. A 2009 randomized control trial of patients with Hurley stage II or stage III receiving three monthly sessions with the Nd:YAG laser demonstrated a statistically significant decrease in Table 3 | Treatment modalities by Hurley stage.

\begin{tabular}{|c|c|c|}
\hline $\begin{array}{l}\text { Hurley } \\
\text { stage }\end{array}$ & $\begin{array}{l}\text { Treatment } \\
\text { modalities }\end{array}$ & Therapies by category \\
\hline \multirow[t]{6}{*}{$\mathrm{l}$} & $\begin{array}{l}\text { Topical } \\
\text { agents }\end{array}$ & $\begin{array}{l}\text { Antibiotics } \\
\text { Clindamycin } \\
\text { Gentamicin } \\
\text { Dapsone } \\
\text { Tetracyclines } \\
\text { Clindamycin + rifampicin } \\
\text { Resorcinol }\end{array}$ \\
\hline & $\begin{array}{l}\text { Systemic } \\
\text { agents }\end{array}$ & $\begin{array}{l}\text { Antibiotics } \\
\text { Rifampicin }+ \text { moxifloxacin }+ \text { metronidazole } \\
\text { Ertapenem } \\
\text { Meropenem } \\
\text { Ceftriaxone }\end{array}$ \\
\hline & & $\begin{array}{l}\text { Anti-androgens } \\
\text { Ethinylestradiol } \\
\text { Cyproterone acetate } \\
\text { Finasteride } \\
\text { Spironolactone }\end{array}$ \\
\hline & & $\begin{array}{l}\text { Biguanides } \\
\text { Metformin }\end{array}$ \\
\hline & $\begin{array}{l}\text { Surgical/ } \\
\text { Laser }\end{array}$ & $\begin{array}{l}\text { Surgical } \\
\quad \text { Deroofing procedure }\end{array}$ \\
\hline & & $\begin{array}{l}\text { Laser } \\
\qquad \mathrm{Nd} \text { :YAG } \\
\mathrm{CO}_{2} \text { laser }\end{array}$ \\
\hline \multirow[t]{4}{*}{$\| I-I I *$} & $\begin{array}{l}\text { Systemic } \\
\text { agents }\end{array}$ & $\begin{array}{l}\text { Biologics } \\
\text { Etanercept } \\
\text { Infliximab } \\
\text { Adalimumab } \\
\text { Ustekinumab }\end{array}$ \\
\hline & & $\begin{array}{l}\text { Retinoids } \\
\text { Acitretin } \\
\text { Alitretinoin }\end{array}$ \\
\hline & & $\begin{array}{l}\text { Immunosuppressants } \\
\text { Methotrexate } \\
\text { Cyclosporine } \\
\text { Colchicine }\end{array}$ \\
\hline & Surgical & Wide radical excision \\
\hline
\end{tabular}

*Includes Stage I treatment modalities 
the severity of $\mathrm{HS}$ (30). The carbon dioxide ( $\left.\mathrm{CO}_{2}\right)$ laser has also been shown to be effective (31). Surgical de-roofing and wide excision are considered to be the only curative treatments for HS because persistent sinus tracts are removed with these techniques. However, effective wide excision involves the removal of large amounts of healthy skin. A special surgical technique, the SkinTissue-sparing Excision with Electrosurgical Peeling (STEEP) technique, was proposed in 2015 as a way to decrease the amount of healthy tissue removed during surgery. STEEP involves taking successive tangential excisions of diseased tissue until reaching the bottom of the sinus tracts. As such, the STEEP technique allows for shorter healing times and fewer contractures than does conventional surgery with wide excision $(28,31,32)$.

Management of SCC in chronic HS is implemented with wide local excision (13). Surgical excision with a minimum of $2 \mathrm{~cm}$ margins and sentinel lymph node evaluation for metastasis is recommended (6). Magnetic resonance imaging or positron emission tomography is useful for evaluating the extent of disease before surgery and as surveillance after surgery. Radiation therapy is only recommended in those patients that do not undergo surgery, and chemotherapy has not been shown to be effective (9). Closure

\section{References}

1. Velpeau A. Dictionnaire de médecine, un repertoire générale des Sciences Medicals sous le rapport theorique et pratique. 2nd ed. Paris: Bechet Jeune; 1839. French.

2. Verneuil A. Etudes sur les tumeurs de la peau; de quelques maladies des glandes sudoripares. Arch Gen Med. 1854;4:447-68. French.

3. Verneuil A. De l'hidrosadénite phlegmoneuse et des abcès sudoripares. Arch Gen Med. 1864;2:537-57. French.

4. Kurayev A, Ashkar H, Saraiya A, Gottlieb A. Hidradenitis suppurativa: review of the pathogenesis and treatment. J Drugs Dermatol. 2016;1:1017-22.

5. Pink A, Simpson M, Brice G. PSENEN and NCSTN mutations in familial hidradenitis suppurativa (acne inversa). J Invest Dermatol. 2011;13:1568-70.

6. Jourabchi N, Fischer AH, Crimino-Mathews A, Waters KW. Squamous cell carcinoma complicating a chronic lesion of hidradenitis suppurativa: a case report and review of the literature. Int Wound J. 2017;14:435-8.

7. Pena ZG, Sivamani RK, Konia TH, Eisen DB. Squamous cell carcinoma in the setting of chronic hidradenitis suppurativa; report of a patient and update of the literature. Dermatol Online J. 2015;21(4).

8. Lavogiez C, Delaporte E, Darras-Vercambre S, Lassalle EMD, Castillo C, Mirabel $X$, et al. Clinicopathological study of 13 cases of squamous cell carcinoma complicating hidradenitis suppurativa. Dermatology. 2010;220:147-53.

9. Huang C, Lai Z, He M, Zhai B, Zhou L, Long X. Successful surgical treatment for squamous cell carcinoma arising from hidradenitis suppurativa. Medicine (Baltimore). 2017;96:1-6.

10. Joglekar K, Jackson C, Kadaria D, Sodhi A. Metastatic squamous cell carcinoma of the pleura: a rare complication of hidradenitis suppurativa. Am J Case Rep. 2016;17:989-92.

11. Hessam S, Sand M, Bechara FG. When inflammation shifts to malignancy: extensive squamous cell carcinoma in a female hidradenitis suppurativa/acne inversa patient. J Dtsch Dermatol Ges. 2016;15:86-8.

12. Maclean GM, Coleman DJ. Three fatal cases of squamous cell carcinoma arising in chronic perineal hidradenitis suppurativa. Ann R Coll Surg Engl. 2007;89:709-12.

13. Yon JR, Son JD, Fredericks C, Morton M, Kingsley S, Gupta S, et al. Marjolin's ulcer in chronic hidradenitis suppurativa: a rare complication of an often neglected disease. J Burn Care Res. 2017;38:121-4.

14. Ingram JR. The genetics of hidradenitis suppurativa. Dermatol Clin. 2016;34: 23-8.

15. Prens E, Deckers I. Pathophysiology of hidradenitis suppurativa: an update. Am Acad Dermatol. 2015;73:S8-11.

16. Panelos J, Massi D. Emerging role of Notch signaling in epidermal differentiation and skin cancer. Cancer Biol Ther. 2009;8:1986-93.

17. Emelianov V, Bechara F, Glaser R, Langan E, Taungjaruqinai W, Schroder J, et al. Immunohistological pointers to a possible role for excessive cathelicidin (LL-37) expression by apocrine sweat glands in the pathogenesis of hidradenitis suppurativa / acne inversa. Br J Dermatol. 2012;16:1023-34. of the surgical site may be accomplished by a split-thickness skin graft or flap. Huang et al. described the utility of administering topical negative pressure to facilitate the formation of granulation tissue and to optimize oxygen tension and wound healing (9).

\section{Conclusion}

HS is a chronic, debilitating skin disorder characterized by the formation of painful abscesses, draining sinus tracts, and scarring in areas of the body rich in apocrine sweat glands. The disease typically presents after puberty, with a peak incidence in the second and third decades of life. Management of HS often involves a combination of therapies, including medical, laser, and surgical. Although rare, SCC is considered the most severe complication arising from chronic HS, with high morbidity and mortality. The management of SCC in HS has not been standardized, but current reports recommend aggressive surgical excision with at least $2 \mathrm{~cm}$ margins. Understanding the risk factors involved in the malignant transformation of HS to SCC is important when deciding on a treatment regimen. There is a need for more research in the field to optimize the medical management of this difficult condition.
18. van der Zee HH, Laman JD, de Ruiter L, Dik WA, Prens EP. Adalimumab (antitumor necrosis factor-a) treatment of hidradenitis suppurativa ameliorates skin inflammation: an in situ and ex vivo study. Br J Dermatol. 2012;166:298-305.

19. Rakoff-Nahoum S. Why cancer and inflammation? Yale J Biol Med. 2006;79:12330.

20. Kurokawa I, Nishimura K, Yamanaka K, Mizutani H, Tsubura A, Revuz J. Cytokeratin expression in squamous cell carcinoma arising from hidradenitis suppurativa (acne inversa). J Cutan Pathol. 2007;34:675-8.

21. Nikolakis G, Liakou AI, Bonovas S, Seltmann H. Bacterial colonization in hidradenitis suppurativa / acne inversa: a cross-sectional study of 50 patients and review of the literature. Acta Derm Venereol. 2017;97:493-8.

22. Jahns AC, Killasli H, Nosek D. Microbiology of hidradenitis suppurativa (acne inversa): a histological study of 27 patients. Acta Pathol Microbiol Immunol Scand. 2014:122:804-9.

23. Kathju S, Lasko LA, Stoodley P. Considering hidradenitis suppurativa as a bacterial biofilm disease. FEMS Immunol Med Microbiol. 2012;65:385-9.

24. Zhang LQ, Tan C. Squamous cell carcinoma arising in chronic hidradenitis suppurativa: a lethal complication to be avoided. Acta Oncologica. 2017;56:497-8.

25. Chahoud J, Semaan A, Chen Y, Cao M. Association between $\beta$-genus human papillomavirus and cutaneous squamous cell carcinoma in immunocompetent individuals: a meta-analysis. JAMA Dermatol. 2016;152:1354-64.

26. Wang J, Aldabagh B, Yu J, Arron ST. Role of human papillomavirus in cutaneous squamous cell carcinoma: a meta-analysis. J Am Acad Dermatol. 2014;70:621-9.

27. Fischer AH, Haskin A, Okoye GA. Patterns of antimicrobial resistance in lesions of hidradenitis suppurativa. J Am Acad Dermatol. 2017;76:309-13.

28. Maalouf E, Faye O, Poli F, Revuz J. Carcinome épidermoïde mortel sur hidradénite suppurée après traitement par infliximab. Ann Dermatol Venereol. 2006;133:473-4.

29. Verdelli A, Antiga E, Bonciani D, Bonciolini V. A fatal case of hidradenitis suppurativa associated with sepsis and squamous cell carcinoma. Int J Dermatol. 2016;55:e52-3.

30. Tierney E, Mahmoud B, Hexsel C, Ozog D, Hamzavi I. Randomized control trial for the treatment of hidradenitis suppurativa with a neodymium-doped yttrium aluminum garnet laser. Dermatol Surg. 2009;35:1188-98.

31. Gill L, Williams M, Hamzavi I. Update on hidradenitis suppurativa: connecting the tracts. F100o Prime Rep. 2014;6:112.

32. Blok J, Spoo J, Leeman F, Jonkman M, Horvath B. Skin-Tissue-sparing Excision with Electrosurgical Peeling (STEEP): a surgical treatment option for severe hidradenitis suppurativa Hurley stage II/III. J Eur Acad Dermatol Venereol. 2015;29:379-82. 